\title{
Can International Law be Enforced Towards its Subjects Within the International Legal Order?
}

\author{
Fajri Matahati Muhammadin \\ Lecturer of International Law International Undergraduate Program \\ Faculty of Law, Universitas Gadjah Mada The Republic of Indonesia \\ Jl. Sosio-Yustisia, Bulaksumur, Sleman, Yogyakarta. \\ fajri.matahati@gmail.com
}

\begin{abstract}
Can international law be enforced? This begs a question, thus problem, in the theory of law: whether there can be enforcement of law in absence of sovereign authority, as is the case of International law. International law has become its own legal order with its own unique way of operating. This writing is a normative research on the sources and reality of the actors of international law. It is found that international law is enforceable and that there are two ways that international law can be enforced, i.e. enforcement by "authorities" formed by treaty regimes, and by non-authorities (including enforcement individual states and by the international community). It is also found that these enforcement means have their weaknesses.
\end{abstract}

Key words : Enforcement, sanction, compliance

\begin{abstract}
Abstrak
Dapatkah hukum internasional ditegakkan? Ini menimbulkan sebuah pertanyaan, sekaligus permasalahan, dalam teori hukum: apakah akan ada penegakan hukum dalam ketidakhadiran pemerintah yang berdaulat, misalnya hukum internasional. Hukum internasional telah menjadi tatanan hukum mandiri yang memiliki cara kerjanya sendiri yang unik. Tulisan ini merupakan sebuah penelitian normatif mengenai sumber-sumber dan realitas pelaku hukum internasional. Diketahui bahwa hukum internasional dapat ditegakkan dan terdapat dua cara untuk penegakkannya, yaitu penegakan oleh "otoritas" yang dibentuk oleh rejim yang berkuasa, dan oleh non-penguasa (termasuk penegakan oleh negara secara individual dan oleh komunitas internasional). Juga diketahui bahwa penegakan semacam ini memiliki kelemahannya masing-masing.
\end{abstract}

Kata kunci: Penegakan, sanksi, kepatuban 


\section{Introduction}

Does international law really exist? This has been one of the most classic theoretical debates in the field of law generally and international law specifically. One of the problems that is at the heart of this debate is the enforceability of international law. ${ }^{1}$ In this particular problem, one may ask: is the existence of enforcement essential as a requirement of a law? Austin, in the $19^{\text {th }}$ century, argues that enforcement is required ${ }^{2}$ while Hart, a little over a century later, argues otherwise. ${ }^{3}$ However, this essay will not indulge in the debate on whether international law is law, or whether a law requires an enforcement mechanism for it to be called a law.

Austin's argument was that a law would require: enforcement in form sanctions for acts of disobedience, and such sanctions are imposed by the sovereign or officials. The fact remains that there is no such thing as a world government acting as a sovereign authority. International politics has and is still witnessing numerous problems which begs a question on whether or not international law can be enforced.

Why has the law been very strong against (the former) Yugoslavia for what it did in the Yugoslav wars, but very silent about Palestine? Why was it so easy for a very large state alliance to be established to fight the 'Islamic State' (formerly the Islamic State of Iraq and Sham or ISIS) who were brutal but in reality has killed not so many civilians, while nothing could be done against the Bashar al-Assad regime of Syria who has clearly killed hundreds of thousands of children?

The situation begs numerous questions. Does the sanctions have to be imposed by a sovereign for the rule to be concluded as 'law'? Or, while we are at it, is there even any law at all? These are questions on whether International law is indeed a law or not. While the necessity of a sovereign authority will be briefly explained in Section III of this essay, but as mentioned earlier, 'whether International law is a law' is not the focus here.

This research will explore the actors of international law which has been found to de facto practice enforcement towards subjects of international law bearching the

\footnotetext{
${ }^{1}$ Oona Hathaway and Scott J. Shapiro, "Outcasting: Enforcement in Domestic and International Law", Yale Law Journal, Vol. 121, No. 2 (2011), pp. 252-349, atpp. 255-256.

${ }^{2}$ John Austin. 1832. The Province of Jurisprudence Determined (found at http://www.koeblergerhard.de/Fontes/ AustinJohnTheprovinceofjurisprudencedetermined1832.pdf, accessed 3 March 2014, 9.24 pm) Brian H. Bix. Legal Positivism. In Martin P. Golding and William A. Edmundson (eds). 2005. The Blackwell Guide to the Philosophy of Law and Legal Theory. Oxford: Blackwell Publishing, p. 39

${ }^{3}$ H. L. A. Hart, The Concept of Law (Second Edition), Oxford University Press, New York, 1994, pp. 217-220
} 
law. First, it will be found that there actually are "authorities" created by treaty regimes. Their nature and shortcomings in enforcing international law will be explored. Second, the focus will shift to "non-authorities". This part, which includes enforcement by individual states an the international community, will show that international law can be enforced despite the absence of "authorities". On both parts, however, it will also be explained that shortcomings also exist.

\section{Research Questions}

This research focuses on the following questions: is international law, despite the absence of a sovereign authority, enforceable? If it is, how is it enforceable? What are the shortcomings of the different ways of enforcing international law that is responsible for the apparent 'mishaps' in the enforcement?

\section{Purpose of Research}

The purpose of this research is to know whether or not international law can be enforced, and to understand the ways and shortcomings of each ways of such enforcement.

\section{Research Method}

This research is a normative research, conducted by observing the sources of international law as well as the conduct of actors of international law, all taken from secondary data (document and literature study only). On the subject of law materials, researches on international law might not follow similar classification to that of national laws. In national law, primary law materials would include authoritative sources (e.g. statutory legislation and judicial decisions) while secondary law materials would include works of scholars.

In international law, however, as Peter Marzuki notes, authoritative sources of law would refer to sources of international law including what is mentioned in Article 38(1) of the ICJ Statute ${ }^{4}$ - which includesthe works of the most highly qualified publicists which would normally be considered as secondary law materials. In that note, Peter

${ }^{4}$ Peter Mahmud Marzuki, Penelitian Hukum (Edisi Revisi), Penerbit Kencana, Rawamangun, 2005, p. 208-209. 
Marzuki did not make a distinction between primary and secondary law materials in discussing law materials in international law. However, only the 'most highly qualified publicists' may be seen as an authoritative source of international law, which may imply some distinction from other 'lesser qualified' (if it could be put that way) work of scholars to be considered as secondary law materials. Tertiary legal materials (e.g. media resources) are used to supplement the other materials. From the available materials, this research will use a qualitative approach to answer the research questions.

\section{Discussion and Result}

\section{Enforcement by "Authorities"}

Austin's view on international law is highly dependent on the historical setting where he lived. Austin says international law is not a law, as it has no sovereign body or officials and sanctions are merely moral.At his time, it may seem that the only model of a sovereign would be governments of states -such authority is explained by many theories,inter alia the social contract theory where the society enters a 'contract' with the sovereign. ${ }^{5}$

However, Austin may have not seen what would come in the next century. Groups of states have gathered and ratified international treaties containing rights and responsibilities to its parties, and also establishing certain bodies to enforce these rights and responsibilities therefore becoming some sort of 'authority' regime for the parties (and in some cases, to non-parties). Examples of such bodies would be the United Nations (UN) with an authoritative organ such as the UN Security Council (UNSC) and the World Trade Organization (WTO) with its Dispute Settlement Body (DSB). These bodies serve as "authorities" due to the treaty provisions which are consented to and therefore binding to the members (as will be explained later). This, to some extent, may resemble the authority of a state to its citizens.

The following would be some comprehensive analysis on how 'authorities' in treaty regimes can enforce international law, using the UNSC and the DSB as samples.

${ }^{5}$ See also the interesting approach by van Apeldoorn saying that the concept of positive law and its authority to be binding the society is some form of contract between the society and sovereign. L. J. van Apeldoorn, PengantarIlmuHukum (translated from Inleiding tot de Studie van het NederlandseRecht), PradnyaParamita, Jakarta, 2008, pp. 155-159 
The Security Council Enforcing the Law of Peace. Article 1(1) of the UN Charter ${ }^{6}$ mentions the first purpose of the UN as well as the desire to enforce it: "To maintain international peace and security, and to that end: to take effective collective measures for the prevention and removal of threats to the peace, and for the suppression of acts of aggression or other breaches of the peace...". ${ }^{7}$

To achieve the purposes of the UN, Article 2 outlines the general obligations of the member states, including the prioritizing of peaceful means to settle dispute as well as the prohibition to the threat or use of force. ${ }^{8}$ It may be interesting to note that Article 2(5) mentions the possibility of the UN to take '...preventive or enforcement action'.Further, the last parts of Article 2(7) mentions the '... application of enforcement measures under Chapter VII' as an exception to what appears to be a non-intervention policy in the first parts of that article.

Chapter VII of the UN Charter, in Article 2(7) being the basis of enforcement, outlines how the UNSC conducts the enforcement, as mandated by the UN in Article 24 , obligatory to all UN members by virtue of Article 25 (even arguably to non-UN members, e.g. Resolution 757 [1992] to Serbia and Montenegro, a non-UN member at the time). These acts of enforcement can be in form of '...measures not involving the use of armed forces...', as per article 41 of the UN Charter, or also use of armed forces as per article 42.

History has shown that measures under article 41 have taken various forms. There has been an arms ban through Resolution No. 418 (1977) against South Africa, economic sanctions and even sports and culture embargo in Resolution 757 (1992) towards the Yugoslavian government. There has been also asset freezes to Iran through Resolution 1737 (2006), and even to non-state actors e.g. terrorist group members through Resolution 1333 (2000).

Further, the SC has established ad-hoc international tribunals to enforce international criminal law, e.g. Resolution No. 827 (1993) establishing the International Criminal Tribunal for the former Yugoslavia, which's legitimacy was challenged by the first defendant before that court (DuskoTadic). ${ }^{9}$ After the establishment of the International Criminal Court (ICC) in 1998, the ICC Statute ${ }^{10}$ provides the possibility

\footnotetext{
${ }^{6}$ Charter of the United Nations (1945)

${ }^{7}$ With added emphasis

${ }^{8}$ Article 2(3) and 2(4) of the UN Charter

${ }^{9}$ Albeit dismissed. See: ICTY: Tadic Case, Trial Chamber Decision on the Defence Motion on Jurisdiction, and Appeals Chamber Decision on the Defence Motion for Interlocutory Appeal on Jurisdiction

${ }^{10}$ Rome Statute of the International Criminal Court (1998)
} 
for the SC to refer the case to it. ${ }^{11}$ The SC first exercised this through Resolution No. 1593 (2005) on the situation in Darfur.

The enforcement of Article 42 of the UN Charter, as previously mentioned, utilizes force to ensure compliance. What may be a straight forward form of this was through Resolution No. 678 (1990) threatening Iraq with armed attack. As consequence of some conditions in the aforementioned SC Resolution, Iraq's force wasthenattacked. ${ }^{12}$ Other forms of application of Article 42 could be naval blockades through Resolution 665 (1990) towards Iraq.

Another act of enforcement that the SC can do is to enforce judgements by the International Court of Justice (ICJ) in case of failure of compliance. This is regulated in Article 94(2) of the UN Charter, which mentions that the SC'..if it deems necessary, make recommendations or decide upon measures to be taken to give effect to the judgment'. One could infer from the mandate of the SC that this might only be done shall the situation is within the domain of maintaining international peace and security. This has been utilized in the case of Bosnia v. Yugoslavia, when the court ordered provisional measures, ${ }^{13}$ and the SC issued Resolution No. 819 (1993). Although this resolution was issued under Chapter VII of the UN Charter, it is still unclear whether such resolution was meant to be a confirmation of the use of Article 94(2) of the UN Charter towards this case as the order was just 'noted' in the preamble and did not mention Article 94(2). ${ }^{14}$

\section{WTO and the DSB}

The WTO is an organization built to face the challenges of globalization by regulating international trade, ${ }^{15}$ with 159 members including states and other economic entities. ${ }^{16}$ The WTO aspires to achieve a global free trade by imposing two main

\footnotetext{
${ }^{11}$ Article 13 of the ICC Statute

${ }^{12}$ John Yoo, "International Law and the War in Iraq", American Journal of International Law, Vol. 97 (2003), pp. 563-576, at p.564.

${ }^{13}$ Application of the Convention on the Prevention and Punishment of the Crime of Genocide, Provisional Measures, Order of 8 April1993, I.C.J. Reports 1993, p. 3; and Application of the Convention on the Prevention and Punishment of the Crime of Genocide, Provisional Measures, Order of 13 September 1993, I. C.J. Reports 1993, p. 325

${ }^{14}$ Attila Tanzi, "Problems of Enforcement of Decisions of the International Court of Justice and the Law of the United Nations”, European Journal of International Law, Vol .6 (1995), pp.539-572, at p.566.

${ }^{15}$ Peter Van den Bossche, The Law and Policy of the World Trade Organization: Text, Cases, and Materials, Cambridge University Press, New York, 2005, p.35.

${ }^{16}$ WTO Official Website.Members and Observers (found at http://www.wto.org/english/thewto e/whatis e/ tif e/org6 e.htm accessed 12 March 2014
} 
principles that should be applied in international trade, i.e.: ${ }^{17}$ 1) Non-Discrimination: A state should treat all other states equally (Most Favored Nation Principle), and should also treat foreign and locals equally (National Treatment Principle); 2) Freer Trade: reducing trade barriers gradually through negotiation;3) Predictability: with binding and transparency; 4) Promoting fair competition: allowing tariffs and certain forms of protection in certain situations; 5) Encouraging development and economic reform: Flexibility for developing countries.

When a member feels violated due to the breach of WTO law by another member or a respondent, the injured member can trigger the mechanism of the DSB governed by the DSU. ${ }^{18}$ At the end of the series of processes, when the DSB has already made a ruling in against the respondent member who then does not comply, the DSB can authorize the injured state to impose certain countermeasures. ${ }^{19}$

An example to this would be the Australia v. Canada salmon dispute, where Canada filed a complaint due to Australia's prohibition on certain kinds of salmon from Canada. This case occurred because Australia prohibited certain imports of salmon from Canada, alleging that it was unsafe for consumption. ${ }^{20}$ The DSB ruled in favour of Canada because it found that Australia did not conduct proper investigation and lack scientific evidence to make such restriction. After that decision, it was Canada's threat to request authorization through the DSB to retaliate that contributed largely to the compliance of Australia towards that ruling. ${ }^{21}$

\section{Shortcomings of the "authority enforcement"}

The capacity of the SC is not without problems, which mostly lies in the realm of politics. The first problem that would rise would be legitimacy issues due to lack of representation and existence of veto rights for the permanent members, ${ }^{22}$ which clearly makes the permanent members (and their allies) immune from the law. Out

${ }^{17}$ WTO Official Website.Principles of the Trading System (found at http://www.wto.org/english/thewto e/ whatis e/tif e/fact2 e.htm\#seebox accessed 20 February 2014)

${ }^{18}$ Understanding on Rules and Procedures Governing the Settlement of Disputes or Dispute Settlement Understanding (1994).

${ }^{19}$ Article 22(6) of the DSU

${ }^{20}$ Case No. WT/DS18/R, 12 June 1998

${ }^{21}$ Steve Charnovitz, "Rethinking WTO Sanctions", The American Journal of International Law, Vol. 95, No. 4 (2001), pp. 792-832, at p.797

${ }_{22}$ David D. Caron, "The Legitimacy Of The Collective Authority Of The Security Council", American Journal of International Law, Vol. 87 (1993), pp.552-588, at p.566 
of 193 members that we have today, the SC only consists of 15 members. ${ }^{23}$ Perhaps all members of the UN have already ratified the UN Charter, therefore meaning that they would have agreed that any decisions by the SC would be binding to them. ${ }^{24}$ However, there is new law that will emerge out of the SC resolutions which might not represent what the majority of UN members desire.

This has been seen after the Nicaragua case, where the ICJ ruled against the USA. ${ }^{25}$ The USA refused to comply with the judgement, and when Nicaragua invoked Article 94(2) of the UN Charter to the SC to demand enforcement, the USA vetoed the attempt. ${ }^{26}$ The UN General Assembly (GA), on the other hand, managed to pass a Resolution No. A/RES/41/31 (1986) which urges the USA to comply to the ICJ judgment. The UN GA has no problems of representation as it consists of all members of the $\mathrm{UN}^{27}$ although their resolutions are not binding. However, the fact that Resolution No. A/RES/41/31 (1986) was adopted (94 for, 3 against, and 47 abstentions) ${ }^{28}$ shows how there can be a big contrast between what the general UN community wishes and the UN Security Council wishes (which even there, the resolution only had one "against" vote, which was the USA).

The use of veto rights has also further prevented actions of the SC on other grave issues. There have been numerous UN GA resolutions condemning Israel gross violations of human rights towards the Palestinians in e.g. No. 2546 (1969) and No. 43/54 (1988), and the Goldstone Commission report bringing more evidence of those violations. ${ }^{29}$ However, no kind of enforcement has ever been done towards the Israel. All the SC has ever done is to "strongly condemn" e.g. through Resolution No. 672 (1990), and even numerous draft resolutions that attempted to 'only' condemn Israel and call for cessation of violations has been vetoed by the USA since the $2000 s^{30}$ let alone make any sanctions. ${ }^{31}$

\footnotetext{
${ }^{23}$ Article 23(1) of the UN Charter

${ }^{24}$ Article 25 of the UN Charter

${ }^{25}$ Militarv and Paramilitary Activities in and against Nicaragua (Nicaragua v. United States of America), Merits, Judgment. I.C.J. Reports 1986, p. 14.

${ }^{26}$ UN Security Council Meeting Record S/PV.2718, 28 October 1986 (found at http://www.un.org/en/ga/

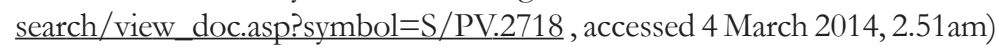

${ }^{27}$ Article 9(1) of the UN Charter

${ }^{28}$ Resolutions adopted by the GA at its $41^{\text {st }}$ Session (found at http://www.un.org/depts/dhl/resguide/

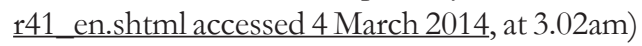

${ }^{29}$ Report of the United Nations Fact-Finding Mission on the Gaza Conflict No. A/HRC/12/48, 25 September 2009.

${ }^{30}$ Security Council Veto List (found at http://www.un.org/depts/dhl/resguide/scact veto en.shtml accessed 4 March 2014 at 3.27am).

${ }^{31}$ SalibaSarsar, "The Question of Palestine and United States Behavior at the United Nations", International Journal of Politics, Culture, and Society, Vol. 17, No. 3 (2004), pp. 457-470, at pp.460-467
} 
The African Union (AU) tension with the ICC is highly related to the SC.One of the reasons of this tension is the alleged 'targeted prosecutions' towards African leaders. ${ }^{32} \mathrm{SC}$ takes part by referring two situations to the ICC: Sudan and Libya. ${ }^{33}$ This is while failing to act upon alleged serious crimes in Palestine, Iraq, Syria, etc. The problem of the WTO enforcement system is that it relies purely on reciprocity by the injured member, which will be explored in the next section.

\section{Enforcement without Authorities}

The previous section has explored that, unlike the international law that Austin may have seen, it is not impossible for international law to have "authority" regimes. This section will show that, even without such "authority" regimes, international law can still be enforced. There are two kinds of enforcement in international law that may occur without authorities, i.e. enforcement by individual states (either retaliation by victim state through reciprocity, or by a third state) and by the international community as a whole. It will also be seen how the effectiveness (or lack there of) may also depend on this category of enforcement.

\section{Individual States}

Hart counters Austin's submission on the necessity of a sovereign in law enforcement, arguing that the sovereign itself is not independent to other kinds of law and influences and therefore law cannot be pictured to definitely require a sovereign. ${ }^{34}$ He notes how custom can be a source of law, where a sovereign does not necessarily exist in that respect. ${ }^{35}$ While Hart mentions that, in a domestic system, customary laws are usually seen as 'subordinate laws', ${ }^{36}$ actually international law recognizes customary laws as a primary source of law. ${ }^{37}$ To understand the nature of customary international law is crucial, especially because it is the oldest kind of law. ${ }^{38}$

\footnotetext{
${ }^{32} \mathrm{Max}$ du Plessis, TiyanjanaMaluwa, and Annie O'Reilly. Africa and the International Criminal Court, p. 2-3 (found at http://www.chathamhouse.org/sites/default/files/public/Research/International\%20Law/0713pp iccafrica.pdf accessed 4 March 2014 at 4.08 am)

${ }^{33}$ SC Resolution No. 1593 (2005) and No. 1970 (2011) for Sudan and Libya respectively

${ }^{34}$ Note 3 , pp. $50-78$

${ }^{35}$ Ibid., p. 49

${ }^{36}$ Ibid., p. 45

${ }^{37}$ Article 38(1)(b) of the ICJ Statute

${ }^{38}$ Malcom Shaw, International Law (Sixth Edition), Cambridge University Press, New York, 2008, pp.72-73
} 
With the constant practice of states feeling a sense of legal obligation (opinion juris), comes customary international law. ${ }^{39}$ What motivates states to comply? Scholars differ on this. Some international lawyers would say that it is that sense of legal obligation that motivates them..$^{40}$ However, international relations theorists have considered another possibility.Game theory analysisshows that the motivation to comply are: the coincidence of interest, coercion, bilateral repeated prisoner's dilemma, and bilateral coordination, all of them essentially practiced in their own dimension by state(s) to maximise their own interest (instead of actual 'sense of legal obligation'). ${ }^{41}$

By this, the enforcement mechanism to comply with the law is reciprocity: if the fact that cooperating (i.e. following rules) would generally ensure maximal benefit to the state(s) own interest, while not cooperating (i.e. violating rules) would generally inflict loss. This is perhaps one of the most concrete and natural enforcement, which comes in form of denying the benefits of social cooperation. ${ }^{42}$

Interestingly, the compliance to international agreements (treaties) may also be due to the same reasons as stipulated in the previous paragraph. ${ }^{43}$ Even the aforementioned SC enforcement stems out of treaty obligation, and we know that the law of treaties started as customary international law as well. ${ }^{44}$

Therefore, the enforcement by the international community by virtue of reciprocity is very important. Although at the start is to be used to explain the relations between two states, reciprocity is repeated into massive scale in the multi-state international community into what will seem to be a regularity of practice. This is either through the massive scale of bilateral reciprocities, or even a collectivity of states towards an individual state. ${ }^{45}$ This section, however, will focus first on the bilateral reciprocity and the acts of individual states only.

\footnotetext{
${ }^{39}$ S.S. Lotus (Fr. v. Turk.), 1927 P.C.I.J. (Ser. A) No.10 (Sept. 7), p.28

${ }^{40}$ Note 38 , p. 80

${ }^{41}$ Jack L. Goldsmith and Eric A., Posner, The Limits of International Law, Oxford University Press, New York, 2005 , p. 40-42

${ }^{42}$ Note 1, p. 302

${ }^{43}$ Ibid., pp. $90-91$

${ }^{44}$ Alan Boyle and Christine Chinkin, The Making of International Law, Oxford University Press, New York, 2007, pp.190-191; see also Note 38, p. 94

${ }^{45}$ Note 41, p. 56
} 


\section{Retaliation of the Injured State through Reciprocity}

A general rule on reciprocity to enforce international law is the rule on countermeasures. Article 22 of the ILC Draft on State Responsibilities for Internationally Wrongful Act $(2001)^{46}$ mentions: "The wrongfulness of an act of a State not in conformity with an international obligation towards another State is precluded if and to the extent that act constitutes a countermeasure taken against the latter State in accordance with chapter II of Part Three".

Among those cited by the ILC in its commentary is the ICJ Gabcikovo-Nagymaros case. ${ }^{47}$ The restriction to that rule is mentioned in Chapter II of Part Three in that same ILC draft: ${ }^{48} 1$. an injured State may only take countermeasures against a State which is responsible for an internationally wrongful act in order to induce that State to comply with its obligations under part two; 2. countermeasures are limited to the non-performance for the time being of international obligations of the State taking the measures towards the responsible State; 3. countermeasures shall, as far as possible, be taken in such a way as to permit the resumption of performance of the obligations in question. Another note is that Article 26 of that Draft mentions that countermeasures may not be done in such a way that it violates peremptory norms (Jus Cogens).

An example of enforcement by reciprocity outside the regime of "authorities" (unlike the WTO DSB) isin the field of international humanitarian law (IHL). It may be important to first note that, as a matter of law, compliance towards IHL principally should not be based on reciprocity.This is based on the Geneva Conventions (1949) in Common Article 1 and 3, mentioning that those provisions apply in 'all circumstances'. The International Committee of the Red Cross understood this to mean, inter alia, that IHL should not be applied based on reciprocity. ${ }^{49}$ The ICJ held similarly in the Namibia Case..$^{50}$ On the level of philosophy, it has even been submitted that IHL is based on altruistic love for a human being. ${ }^{51}$

However, reality shows that reciprocity does play a major role in the respect towards the laws and customs of war and used as an enforcement mechanism. Even

\footnotetext{
${ }^{46}$ Hereinafter the "Draft on SR"

${ }^{47}$ Gabcikovo-Nagymaros Project (Hungary v. Slovakia), Judgment, 1. C. J. Reports 1997, p. 7, para 83

${ }^{48}$ Article 48, Draft on SR

${ }^{49}$ Louis Doswald-Beck, and Jean-Marie Haenckarts. 2005. ICRC Customary International Humanitarian Law, Vol. I, Rules. Cambridge: Cambridge University Press, pp.498-499

${ }^{50}$ Legal Consequences for States of the Continued Presence of South Africa in Namibia (South West Africa) notwithstanding Security Council Resolution 276 (1970), Advisory Opinion, I.C.J. Reports 1971, p. 16., para.96

${ }^{51}$ See generally, Eva Wartel, "Humanitarians and their moral stance in war: the underlying values", International Review of the Red Cross, Vol. 91, No. 876 (2009), pp.779-802
} 
in history of warfare, combatants have some general understanding that there is a benefit to: respecting surrenders and wounded opponents, refrain from treacherous acts, etc..$^{52}$ As failure to respect that, there are examples of reprisals as retaliation to violations, such as King Saladin executing French prisoners of war in retaliation to the Crusaders executing Muslim civilians. ${ }^{53}$

Even in a more modern context of IHL, some extent of reciprocity may have role. An evidence to this is the existence of belligerent reprisals.Traditionally, belligerent reprisals might not necessarily be in conformity with IHL per se, as by definition it does mean to conduct an unlawful act as retaliation to another unlawful act by the adverse party. ${ }^{54}$ However, there seems to be room for belligerent reprisals with certain restrictions.

The Kupreskic Casedoes mention that belligerent reprisals can be legal as long as they fulfil a few requirements: done as last resort to ensure adversary compliance to IHL, taking precautionary measures, proportionality, and elementary considerations of humanity. ${ }^{55}$ This is generally consistent with practices stemming from Article 27 of the Lieber Code, for example the UK's reservation to Article 51-55 when ratifying the Additional Protocol I to the Geneva Conventions (1977). ${ }^{56}$ Bear in mind that Article 51-55 of the aforementioned Protocol regulates the protection of civilians and other objects in times of war, with a particular interest in 51(6) and 52(1) which explicitly prohibits reprisals towards civilians. Belligerent reprisals towards civilians is exactly the type of reprisals that was specifically prohibited by the Kupreskic Case (although admitting that some authorities may say that some belligerent reprisals to civilians can be lawful, as there are not sufficient state practice to indicate a general rule prohibiting it entirely). ${ }^{57}$

\footnotetext{
${ }^{52}$ Sean Watts, "Reciprocity and the Law of War", Harvard International Law Journal, Vol. 50, No. 2 (2009), pp.365434, at pp.387-388

${ }^{53}$ Guizot, M., A Popular History of France from the Earliest Times: Vol II. Boston: Dana Estes \& Charles E. Lauriat.

${ }^{54}$ Milan Kuhli and Klaus Gunther, "Judicial Lawmaking, Discourse Theory, and the ICTY on Belligerent Reprisals”, German Law Journal, Vol. 12 No. 5 (2011), pp. 1261-1278, at p.1268

${ }^{55}$ ICTY: Kupreskic et al Case, Trial Chamber Judgment, para. 535

${ }^{56}$ ICRC Official Website. Ratification of the Additional Protocols by the United Kingdom of Great Britain and Northern Ireland (found at http://www.icrc.org/eng/resources/documents/misc/57jp54.htm accessed 6 March 2014, 10.05am)

${ }^{57}$ Note 55, para 522 and 527.

${ }^{58}$ Shane Darcy, “The Evolution Of The Law Of Belligerent Reprisals”, Military Law Review, Vol. 175 (2003), pp. 184-251, at pp.220-244
} 
There are controversies to the extent of which belligerent reprisals can be lawful..$^{58}$ However, the previous authorities are clear that the idea of belligerent reprisals in general is a lawful way of enforcing compliance to IHL.

\section{Unilateral Actions by Third Parties}

The previous subsection talked about how victims of the particular rule violation could react in such a way to enforce compliance towards the state that made such violation, as a consequence of reciprocity. This subsection, on the other hand, will explore individual state(s) role in enforcing international law despite not directly being victim of that particular rule.As the cases will show, unilateral actions by third parties are usually doneto assist the direct victim due to the request or helplessness of the latter.

Article 48 of the Draft on SR mentions: 1. Any State other than an injured State is entitled to invoke the responsibility of another State in accordance with paragraph 2 if: (a) The obligation breached is owed to a group of States including that State, and is established for the protection of a collective interest of the group; or (b) The obligation breached is owed to the international community as a whole.

See also Article 54: "This chapter does not prejudice the right of any State, entitled under article 48, paragraph 1, to invoke the responsibility of another State, to take lawful measures against that State to ensure cessation of the breach and reparation in the interest of the injured State or of the beneficiaries of the obligation breached"

Particularly focusing on Article 48(1)(b) there, the logic is that if there are certain obligations that is owed to the entire international community as a whole, then any state will have interest despite not actually having direct interest per se. The ICJ mentioned this kind of obligation in the Barcelona Traction Case ${ }^{59}$ which was also cited in the ILC commentaries to the Draft of SR. ${ }^{60}$ An example of an ergaomnesobligation is to comply with the rules in the Convention Against Torture, as the ICJ held in $2012 .{ }^{61}$

There are two possible ways to enforce these ergaomnesobligations by a noninjured state: by individual state(s) and collectively by the international community through collective mechanisms. This particular subsection (as did the entire section) will focus on individual state(s) first.

\footnotetext{
${ }^{59}$ Barcelona Traction, Light and Power Company, Limited, Judgment, I.C.J. Reports 1970, p. 3., para.33

${ }^{60}$ Draft articles on Responsibility of States for Internationally Wrongful Acts, with commentaries (2001), p.126

${ }^{61}$ Questions relating to the Obligation to Prosecute or Extradite (Belgium v. Senegal), Judgment, I.C.J. Reports 2012, p. 422, para 69
} 
There are a number of instances where individual states have been taking part in enforcingergaomnes obligations. An example would be the arrest of Augusto Pinochet in Britain. What happened to Pinochet was the first time when a former head of state (who would normally enjoy immunity from jurisdiction of the courts of other states) was declared to be subject to the jurisdiction of another state's national court.

Spanish Judges issued an international arrest warrant against Pinochet for numerous crimes towards Spanish nationals in Chile, including torture. ${ }^{62}$ Pinochet was then arrested and the UK courts processed the possibility of extraditing him to Spain..$^{63}$ Finally, the UK House of Lords decided that it can extradite Pinochet, despite the (former) head of state immunity enjoyed by him. ${ }^{64}$ However, Pinochet was then released as he was later seen to be medically unfit. ${ }^{65}$ This particular case became an important case, which had to be carefully examined by the ICJ's Arrest Warrant Case and is understood to display how former heads of states do not enjoy immunity from jurisdiction in case of ergaomnesviolations. ${ }^{66}$

Other instances where third parties have unilaterally enforced international obligations would be embargos towards Israel due to the violence perpetrated towards the Palestinians by the Arab League nations. The member states of the Arab League have boycotted Zionist-related interests since 1945, and formally organized an economic boycott to the State of Israel since $1948 .{ }^{67}$ The boycott has three tiers, which are to prohibit (although not binding to) the Arab League nations from having: ${ }^{68} 1$. business relations with the Israeli government or citizen; 2. business relations with any entities world-wide that does business with Israel; 3. business relations companies that in turn deals with companies that have been blacklisted by the Arab League; 4 . the enforcement of the boycott varies. Some never did the boycott (e.g. Mauritania), some only enforce the first tier (e.g. Saudi Arabia, and even then, they are trying to

\footnotetext{
${ }^{62}$ Andrea Bianchi, 'Immunity versus Human Rights: The Pinochet Case", European Journal of International Law, Vol.10 (1999), pp.237-277, p. 238

${ }^{63}$ Ibid.

${ }^{64}$ R. v Bow Street Stipendiary Magistrate Ex. P. PinocetUgarte (No. 3) [2000] 1 A.C. 147

${ }^{65}$ BBC News. Pinochet Set Free, 2 March 2000 (Found at http://news.bbc.co.uk/1/hi/uk/663170.stm accessed $\underline{8 \mathrm{March} 2014}, 11.17 \mathrm{pm})$

${ }^{66}$ Arrest Warrant of 11 April 2000 (Democratic Republic of the Congo v. Belgium), Judgment, I.C.J. Reports 2002, p. 3 , para. 56-57

${ }^{67}$ Martin A. Weiss, Arab League Boycott of Israel.Congressional Research Service Report for Congress, 19 December 2013 (Found at https://www.fas.org/sgp/crs/mideast/RL33961.pdf accessed 8 March 2014 at 11.46pm), p.1

${ }^{68}$ Ibid., p. 2
} 
avoid the boycott) and then eliminated it completely, and only Lebanon is enforcing all tiers of the boycott. ${ }^{69}$

More recently, other states have also started small but clear hard actions to build up further pressure to Israel. Among them, Norway's finance ministry excludes certain Israel firms from government pension funds, while Romania has forbidden its citizens to work in West Bank companies. ${ }^{70}$ This is after the European Union (although not exactly an individual state) released a Guideline on Activities in Israel Occupied Territories, ${ }^{71}$ which outlines a number of policies that also apply pressure towards Israel (e.g. not recognizing the occupied territories as lawfully occupied, and the cutting of EU supports regarding activities in those areas).

Military intervention may be one of the forms of ways which states have done to enforce compliance towards international law.Normally, the use of force is prohibited under Article 2(4) of the UN Charter. However, as mentioned previously in the section of Enforcement by "Authorities", Article 42 of the UN Charter provides possibility for the SC to authorize legitimate uses of force to enforce compliance towards certain international obligations. An example to this would be the armed attack towards Iraqi forces by the USA-led forces in 1991 as previously explained already. This is both an example of enforcement by the SC as well as by individual state(s).

\section{Shortcomings of Actions by Individual States}

It has been mentioned how the compliance of states towards legal obligations are governed more by their own interest rather than that of their sense of legal obligation. ${ }^{72}$ The only logical consequence to that is if there is a collision between 'obeying legal obligations' and 'obtaining interest', certainly the choice will not be the former. It is generally more beneficial for states to cooperate even when not necessarily always achieving maximum or any interest at all, but then at least losses can be minimized. ${ }^{73}$

\footnotetext{
${ }^{69}$ Ibid., p. 2-3

${ }^{70}$ The Economist.Sanctions Against Israel: A Campaign That Is Gaining Weight, 8 February 2014 (Found at http:/ Lwww.economist.com/news/middle-east-and-africa/21595948-israels-politicians-sound-rattled-campaign-isolate-theircountry accessed 9 March 2014 at 00.15 am)

${ }^{71}$ Guidelines on the eligibility of Israeli entities and their activities in the territories occupied by Israel

since June 1967 for grants, prizes and financial instruments funded by the EU from 2014 onwards (2013/C 205/05)

${ }^{72}$ See Note. 41 especially

${ }^{73} \mathrm{Ibid}$
} 
However, this is but a general conclusion that does not exempt the possibility of states to always cooperate. Not only that there are times where indeed greater interest can be achieved (or greater loss can be avoided) by violating rules, but also the schemes of cooperation does allow the possibility of repairing relations after such violations are done. ${ }^{74}$

Such a scenario illustrated in the previous paragraph is certainly an over simplification. The complexity of real world politics will show how there can be more incentives for states to not comply with rules and act on personal interest instead. Following the same logic, enforcement measures conducted by individual states can also be done to pursue personal interest -particularly in situations where this personal interest collides with legal obligations.

Agrand example to this would be the USA's attitude towards Israel with respect to violations towards the Palestinians. This example will show how the act of individual states can,instead of enforce compliance towards international obligations, but enforce the violation towards that international obligation as well as secure it from other attempts of enforcements.

There is no question on the intimacy of relationship between the USA and Israel on so many areas, including but not limited to: military, economic, political, etc. ${ }^{75}$ One of the aforementioned shortcomings of the SC as enforcement is at the same time a shortcoming of individual state(s) conducting enforcement. It has already been explored how the acts of Israel towards the Palestinians are clearly unlawful and has been condemned by an overwhelming majority of states. It has also been noted how the failure of the SC to issue any binding sanctions or even condemnations towards Israel is due to the Veto of the USA.

Outside the UN arena, it is seen that the acts of the USA enforces its own interest rather than that of the international legal obligations. An example to this would be the military cooperation. The success of the building of weapons and defence industry in Israel is owed to the aid of the USA. ${ }^{76}$ It is not difficult to connect this military cooperation to the violations committed by Israel, bearing in mind the Israeli weapon

\footnotetext{
${ }^{74}$ Robert Axelrod. 1984. The Evolution of Cooperation. New York: Basic Books, Inc, pp.27-54

${ }^{75}$ Note 31, at pp.460-462

${ }^{76}$ Jeremy M. Sharp. U.S. Foreign Aid to Israel.Congressional Research Service Report for Congress, 12 March 2012 (Found at http:/ / fpc.state.gov/documents/organization/187412.pdf accessed 9 March 2014 at 2.33am), p.1
} 
company websites (e.g. Israel Military Industry ${ }^{77}$ and Israel Weapon Industry ${ }^{78}$ ) describe most if not all of their products to be 'combat-proven'.

Another example of a 'third state enforcement' was the 2003 Iraq invasion. Unlike the 1991 invasion which has no question in its legality, the US-led invasion to Iraq was an example of virtually unquestionable illegality. They had a two layered justifications for the invasion: 1. Enforcing SC Resolution 678 (1990) and 687 (1991), due to material breach of peace conditions by Iraq ${ }^{79} 2$. Self-defence towards Saddam Hussein's threats. ${ }^{80}$

However, overwhelming voices from States both in the UNGA and SCisevidence how the international community neither supports such understanding of the aforementioned SC Resolutions, nor is there any threattowards international peace that might justify the claim of Self Defence. ${ }^{81}$ Yet, as we have witnessed, the invasion happened anyway. It is not hard to conclude that, no matter how obvious was the USA violations were, the SC will never be able to act due to USA's veto rights.

The problem of enforcement by individual states does not necessarily lie in the priority of state interest as opposed to international legal obligation. There are instances where problems can be caused by difference of interpretations of what the legal obligations are. The first example to this would also be the USA invasion to Iraq in 2003. The act by the USA is actually not necessarily a blatant disregard of law. If other motivations are put aside, we can see the problem as USA offering an interpretation of law that just so happens to be against the international community's interpretation. It just so happens that, in this context, the latter's interpretation would be seen as more authoritative.

Another example to that would be the ICJ Arrest Warrant Case. An international arrest warrant in absentia was issued against Congo's Foreign Minister for war crimes and crimes against humanity under universal jurisdiction. ${ }^{22}$ The way Belgium understands the law, immunity from criminal jurisdiction is not enjoyed for acts

\footnotetext{
${ }^{77}$ Official Website of Israel Military Industry (http://imi-israel.com/home/doc.aspx?mCatID=68506 accessed at 9 March 2014 at 2.40am)

${ }^{78}$ Official Website of Israel Weapon Industry (http://www.israel-weapon.com/default.asp?catid =\%7BFF7A51A4-4AF9-410D-A2B0-860E9D4F6D2F\%7D accessed at 9 March 2014 at $2.31 \mathrm{am}$ )

${ }^{79}$ Alex Bellamy, "International Law and the War in Iraq", Melbourne Journal of International Law, Vol. 4, No. 2, (2003), pp. 497-520, at pp.502-504

${ }^{80}$ Ibid., p. 513

${ }^{81}$ Ibid., p.519 (or generally, for a detailed discussion on the matter); The Guardian.Ten Days to War, 8 March 2008 (found at http://www.theguardian.com/world/2008/mar/08/iraq.unitednations accessed 9 March 2014 at 3.16am)

${ }^{82}$ Arrest Warrant Case, para 13-15
} 
outside official capacity especially when committing serious crimes. ${ }^{83}$ However, the ICJ ruled there is no basis in customary international law to support Belgium's claim. ${ }^{84}$ Some judges in this case dissented in support of Belgium's argument, ${ }^{85}$ others saw the arrest warrant ceasing to be illegal when the Congo Foreign Minister ceases to hold office. ${ }^{86}$

Reciprocity does seem to be a simple effective way of enforcement, however there can still be problems that rise in it. The aforementioned problem of different interpretation could complicate the situation. The analysis on belligerent reprisals in the subsection Pushing Compliance by Reciprocity can serve as an example of enforcement through reciprocity that is very potential to go sour. It has been shown how there can be differences of understanding in the extent of possible legal reprisals, even involving possibilities of civilians being targets of reprisals. There is no need to repeat the analysis. It is not hard to imagine how the uncertainty of the law in this particular area can potentially increase losses from war.

Further, the reality of world politics also makes things harder. While the ideal situation of reciprocity can occur in a world where all states are equal in position and strength, the truth is that some states are weak and others are strong. ${ }^{87}$ This affects the capability of states both in conducting itself in the international arena. An example to this would be the Germany invasion to Poland in 1939. Theoretically, Poland could reciprocate the invasions by Germany (and later joined by Soviet) and exercise their self-defence rights, but Poland was certainly no match for both military giants even individually. ${ }^{88}$

Another case of failure of reciprocity would be when exercising enforcement would bring more costs to the injure state rather than that of the violator state. An example of this would be the Beef Hormones case in the WTO where the European Community (EC, now the European Union) banned USA beef containing artificial beef hormones. ${ }^{89}$ When the EC did not complywith the ruling, the DSB authorized the USA to impose countermeasures to EC. ${ }^{90}$

\footnotetext{
${ }^{83}$ Ibid., para.49-50, 56

${ }^{84}$ Ibid., para. 58

${ }^{85}$ See Ibid., Dissenting Opinion of Judge Al-Khasawneh and Judge ad hoc Van den Wyngaert

${ }^{86}$ See Ibid., Joint Separate Opinion of Judges Higgins, Kooijmans and Buergenthal

${ }^{87}$ Alain Pellet, "The Normative Dilemma: Will and Consent in International Law Making", Australian Yearbook of International Law, Vol. 12, (1992), pp.22-53, at pp.42-43

${ }^{88}$ Daniel Paliwoda, "Review of The Eagle Unbowed: Poland and the Poles in the Second World War", Military Review, Vol. 93, No. 2, (2013), pp.100-106, at p.100

${ }^{89}$ Case No. WT/DS26/AB/R - WT/DS48/AB/R, 16 January 1998

${ }^{90}$ Note 21, p. 794
} 
Similarly, the Banana Case at the WTO responded to a situation where the EC set an import quota on Bananas. In this case, the DSB declared that such action by the EC was in breach of the WTO principles. ${ }^{91}$ Further, after the EC decided not to comply, the DSB authorized the injured states (USA and a number of Latin American states) to retaliate by imposing sanctions to the EC.The USA consumers took the hit by loss of choice and higher prices for substitute products resulting in an overall efficiency loss, while Ecuador chose to not use retaliation at all..$^{92}$ These cases show how retaliation is sometimes not a good way of enforcing, since it may also hurt the state that is enforcing.

\section{Enforcement by the International Community}

The previous section has explained an alternative view on compliance towards international law, other than 'sense of obligation', which is the natural enforcement by other states in international relations. It can be in form of reciprocity by the affected state, as well as by a third state. It has been briefly mentioned how reciprocity, in a multi-state context, can multiply on a massive scale into a general behaviour of state. And in that context as well, we have what we call an "international community". We have seen how individual states have represented this international community in enforcing international obligations. This section will explore how states collectively act as international community in enforcing international law.

\section{Pressureby the International Community}

It has been mentioned as well in the previous section, how the form of enforcement in this context is in form of denial of certain benefits of social cooperation, where states have found that compliance will generally help them enjoy such benefits.

A first aspect to this would be the phenomena of soft law. Traditionally, soft laws are non-binding. ${ }^{93}$ However, they are generally complied with. An example to this would be GA resolutions.

There is a reason why this essay did not include the GA (or UN bodies other than the SC) as an enforcement body in the section of Enforcement by "Authorities",

\footnotetext{
${ }^{91}$ Ibid

${ }^{92}$ Ibid, p.814-815

${ }^{93}$ Bryan A. Gardner (ed.), Blacks Law Dictionary (9th ed.), St. Paul, MN: West, 2009, p.1519; and see also Note 38 at p.213
} 
which is because the GA was not meant to be an enforcement body. Resolutions passed by the GAare actually not formally binding (See Chapter IV of the UN Charter, showing how the GA can only 'recommend'). However, the GA has de facto been a forum of enforcement due to the impact of the collectivity of states behind it. They have regulated many things that have then been followed internationally as they can only pass when supported by a majority of GA members (i.e. almost the entire world). A testimony to that would be GA resolutions on state control towards natural resources Resolution No. 3281 (A/RES/29/3281), No. 3201 (A/RES/S-6/3201), No. 3171 (A/RES/3171), and No. 1803 (A/RES/1803), which is actually followed. ${ }^{44}$

What the GA example above wishes to display is that then, there will be pressure towards and by each other to actually follow these resolutions, as they reflectopiniojurisand later generate state practice in forming customary laws. ${ }^{95}$ This pressure acts as enforcement for each other's compliance just like any other social cooperation, as explained in the beginning of the previous section.

The UNcan also become a more explicit pressureforum by the internationalcommunity. An example to this would be pressure towards the USA in the AIDS patents problem. The USA tried to file against a complaint against Brazil to the WTO due to an alleged breach of the TRIPS (Agreement on Trade Related Aspects of Intellectual Property Rights),despite such alleged breach was done by Brazil to combat an AIDS epidemic. ${ }^{96}$ However, international pressure came on to the USA especially through the UN Commission on Human Rights (CHR) Resolution No. 2001/33, declaring that the right to access AIDS medicine in situation of epidemic is a human right. ${ }^{97}$ The pressure towards the USA was so high that on the first day of the UN GA Special Session on AIDS (which also adopted the CHR Resolution's content in the Joint Declaration)they had to send a letter to Brazil to set the problem aside, and then also dropped the complaint at the WTO. ${ }^{98}$

It is elusive to assume that the above is a case of 'enforcement to international law compliance'. It may be argued that if the right to the highest attainable standard of health ${ }^{99}$

\footnotetext{
${ }^{94}$ Gregory J. Kerwin, “The Role of United Nations General Assembly Resolutions in Determining Principles of International Law in United States Courts”, Duke Law Journal, Vol. 32, No. 4 (1983), pp.876-899, at p. 883

${ }^{95}$ Note 44, p. 77

${ }^{96}$ Andreas Fischer-Lescano and Gunther Teubner, "Regime-Collisions: the Vain Search for Legal Unity in the Fragmentation of Global Law”, Michigan Journal of Internatonal Law, Vol.25 (2004), pp. 999-1046, at pp. 1024-1025

${ }^{97}$ See also: Ibid., 1028

${ }^{98}$ Ibid.

${ }^{99}$ Article 12, International Covenant on Economic, Social, and Cultural Rights (1966)
} 
is to (according to the belief of most states) include the access towards medicine in situation of epidemic, which also includes setting aside patents, this international pressure is a move to safeguard such rights. Or even if the argument is not accepted, at least it is an evidence of international pressure that can direct state behaviour.

Pressure does not have to be from the entire international community, as it can be in form of only a few states. An example to this would be the enforcement of the Land and Maritime Boundary Case. ${ }^{100}$ Nigeria decided that it could 'cherry-pick', declaring to follow only the parts they considered fair or favourable and rejected those deemed unacceptable. ${ }^{101}$ It was the USA, France, and the UK who pressured Nigeria to comply with the judgment. ${ }^{102}$ The UN did have a role in this situation, but they played the 'good cop' instead of pressurizing, to help Cameroon and Nigeria negotiate further to resolve the matter peacefully. ${ }^{103}$

International pressure could be manifested further in form of economic sanctions. It is obvious that the more states that apply sanctions, the more effective it will be. When Libya failed to cooperate in the investigation of Lockerbie incidents demanded by SC Resolution 731 and 748 (both in 1992), the SC resorted to economic sanctions and travel bans towards Libya through SC Resolution 883 (1993). This is an example of enforcement by the SC, but seeing how the sanction was carried out it is also an example of enforcement by the international community. SC Resolution 883 (1993) imposed obligation to do sanctions to the all states. ${ }^{104}$ Due to this international sanction, Libya decided to cooperate. ${ }^{105}$

Sanctions need not to be committed by the international community through the UN. An example to that would be the sanctions against Myanmar due to the reign of the Junta military who were violating human rights by oppressingtheir own people. These various forms of sanctions were applied by the EU, USA, Canada, Japan, ${ }^{106}$ and Australia. ${ }^{107}$ After

${ }^{100}$ Land and Maritime Boundary between Cameroon and Nigeria (Cameroon v. Nigeria: Equatorial Guineu intervening), Judgment, 1. C. J. Reports 2002, p. 303

${ }^{101}$ Aloysius P. Llamzon, "Jurisdiction and Compliance in Recent Decisions of the International Court of Justice", European Journal of International Law, Vol. 18 No.5, (2008), pp.815-852, at p.836

${ }^{102}$ Ibid., pp.836-837

${ }^{103}$ Ibid., p.837

${ }^{104}$ See particularly Operative Clauses 3 and 6

${ }^{105}$ Note 1, p. 312

${ }^{106}$ ALTSEAN Burma.Ready, Aim, Sanction.Special Report November 2003 (found at http://www.altsean.org/ Docs/PDF\%20Format/Special\%20Reports/Ready\%20Aim\%20Sanction.pdf accessed at 10 March 2014 at $11.51 \mathrm{pm}$ )

${ }^{107}$ Australian Government Department of Foreign Affairs and Trade Official Website.Burma Country Brief (found at http://www.dfat.gov.au/geo/burma/burma brief.html accessed at 10 March 2014 at 11.53pm) 
significant progress in Burma (e.g. proper elections, democratic regime), some of these sanctions were lifted. ${ }^{108}$

\section{Shortcomings of Enforcement by the International Community}

The weakness of international pressure lies in the basic construction of the system. As previously mentioned, states will only do what is best in their interest, and sometimes obeying rules are not in their best interest. The idea of enforcement in any case is to construct the situation in such a way that it is no longer in the state's best interest to break the rules. ${ }^{109}$

However, not all members of the international community can actually give any significant effect to actually pressure the particular state. An example to that would be the Land and Maritime Boundary Case. Surely, if very small states like Vanuatuapply the most stringent sanction, it is hard to imagine that there will be any actual effects. This is perhaps why it had to be the UK, France, and the USA that took part in the pressures. The more serious effect, though, would be in the fact that the attempts of an overwhelming majority can be thwarted by a very small minority (in quantity).

The situation where that could happen is when the law is violated by a very powerful state, or an ally to that very powerful state. It has been shown in the previous subsection how the USA can succumb to international pressure at times, but in the section of Enforcement by "Authorities" we have seen how the USA still refused to comply with the Nicaragua Case judgement despite a GA Resolution passed against them. Another example is how China could get away with all the human rights abuses that it has done (e.g. the Tiananmen massacre), not only because it has veto rights in the SC, but also because they are such a big international superpower so that they could just ignore the pressure, or claiming to take 'commitments' but without any concrete results. ${ }^{110}$

\footnotetext{
${ }^{108}$ Wall Street Journal.Sanctions Lifted Against Myanmar, 22 April 2013 (found at http:/ /online.wsi.com/news/ articles/SB10001424127887323735604578438632149787290 accessed at 11 March 2014 at 00.10am)

${ }^{109}$ Note 41, p.28-29

${ }^{110}$ Sonia Cardenas, "Norm Collision: Explaining the Effects of International Human Rights Pressure on State Behavior", International Studies Review, Vol.6, No.2 (2004), pp. 213-231, at p.226
} 


\section{Conclusion}

This essay has displayed how enforcement exists in international law. Such enforcement comes in two ways: through "authority" regimes formed through treaties, such as the WTO and the UN, or without "authority" regimes, such as enforcement by individual states or the international community as a whole.

However, it is also found that each of these means of enforcements has their shortcomings which may hinder their effectiveness. Enforcement by “authority" regimes may rely on support of the international community and, depending on the construction of that "authority" (e.g. veto rights, etc), certain individual states as well. On the other hand, enforcement by unilateral actions by individual states also has its weaknesses. Enforcement by individual states can be very highly influenced by that state's own (unlawful) interest, can be thwarted due to different legal interpretations by the "authority" regime or international community, and only works depending on the strength of that particular state. The international community, when acting as a whole, may seem to be very strong in enforcing international law. However, due to either the construction of the "authority" regimes or the political power of that particular individual state, enforcements by the international community can be thwarted too.

\section{Bibliography}

van Apeldoorn,L. J. PengantarIlmuHukum (translated from Inleiding tot de Studie van het NederlandseRecht, Pradnya Paramita, Jakarta, 2008.

Austin, John, The Province of Jurisprudence Determined, 1832. (found at http:/ / www. koeblergerhard.de/Fontes/AustinJohnTheprovinceofjurisprudencedetermined1832.pdf, accessed 3 March 2014, 9.24 pm)

Axelrod, Robert, The Evolution of Cooperation, Basic Books, Inc, New York, 1984.

Bellamy, Alex, "International Law and the War in Iraq", Melbourne Journal of International Law, Vol. 4, No.2, 2003.

Bianchi, Andrea, “ Immunity versus Human Rights: The Pinochet Case”, European Journal of International Law, Vol.10, 1999.

Bossche, Peter Van den. The Law and Policy of the World Trade Organization: Text, Cases, and Materials, Cambridge University Press, New York, 2005.

Boyle, Alan and Christine Chinkin, The Making of International Law, Oxford University Press, New York, 2007. 
Cardenas, Sonia, "Norm Collision: Explaining the Effects of International Human Rights Pressure on State Behavior", International Studies Review, Vol. 6, No. 2, 2004.

Caron, David D.," The Legitimacy Of The Collective Authority Of The Security Council", American Journal of International Law, Vol. 87, 1993.

Charnovitz, Steve," Rethinking WTO Sanctions", The American Journal of International Law, Vol. 95, No. 4, 2001.

Darcy, Shane, “The Evolution Of The Law Of Belligerent Reprisals”, Military Law Review, Vol. 175, 2003.

Doswald-Beck, Louis, and Jean-Marie Haenckarts, ICRC Customary International Humanitarian Law Vol I: Rules, Cambridge University Press, Cambridge, 2005.

Fischer-Lescano, Andreas and Gunther Teubner, "Regime-Collisions: the Vain Search for Legal Unity in the Fragmentation of Global Law", Michigan Journal of Internatonal Law, Vol.25, 2004.

Gardner, Bryan A. (ed.), Blacks Law Dictionary (9th ed.), St. Paul, MN, West, 2009.

Golding, Martin P, and William A. Edmundson (eds). The Blackwell Guide to the Philosophy of Law and Legal Theory, Blackwell Publishing, Oxford, 2005.

Goldsmith, Jack L. and Eric A. Posner. The Limits of International Law, Oxford University Press, New York, 2005.

Guizot, M., A Popular History of France from the Earliest Times: Vol II. Boston: Dana Estes \& Charles E. Lauriat.

Hart, H. L. A., The Concept of Law (Second Edition), Oxford University Press, New York, 1994.

Hathaway, Oona and Scott J. Shapiro, "Outcasting: Enforcement in Domestic and International Law", Yale Law Journal, Vol. 121, No. 2, 2011.

Kerwin, Gregory J., “The Role of United Nations General Assembly Resolutions in Determining Principles of International Law in United States Courts", Duke Law Journal, Vol.32, No. 4, 1983.

Kuhli, Milan and Klaus Gunther,"Judicial Lawmaking, Discourse Theory, and the ICTY on Belligerent Reprisals", German Law Journal, Vol. 12 No. 5, 2011.

Llamzon, Aloysius P., "Jurisdiction and Compliance in Recent Decisions of the International Court of Justice" European Journal of International Law, Vol. 18 No.5, 2008.

Marzuki, Peter Mahmud, Penelitian Hukum (Edisi Revisi), Penerbit Kencana, Rawamangun, 2005.

Paliwoda, Daniel, "Review of The Eagle Unbowed: Poland and the Poles in the Second World War", Military Review, Vol. 93, No. 2, 2013.

Pellet, Alain, “The Normative Dilemma: Will and Consent in International Law Making", Australian Yearbook of International Law, Vol. 12, 1992. 
duPlessis, Max, TiyanjanaMaluwa, and Annie O'Reilly. Africa and the International Criminal Court (found at http://www.chathamhouse.org/sites/default/ files/public/Research/International\%20Law/0713pp_iccafrica.pdf accessed 4 March 2014 at 4.08 am )

Report of the United Nations Fact-Finding Mission on the Gaza Conflict No. A/ HRC/12/48, 25 September 2009

Sarsar, Saliba, "The Question of Palestine and United States Behavior at the United Nations", International Journal of Politics, Culture, and Society, Vol. 17, No. 3, 2004.

Sharp, Jeremy M..U.S. Foreign Aid to Israel.Congressional Research Service Report for Congress, 12 March 2012 (Found at http://fpc.state.gov/documents/ organization/187412.pdf accessed 9 March 2014 at 2.33am)

Shaw, Malcom, International Law (Sixth Edition), Cambridge University Press, New York, 2008.

Tanzi, Attila,"Problems of Enforcement of Decisions of the International Court of Justice and the Law of the United Nations", European Journal of International Law, Vol . 6, 1995.

Wartel, Eva, "Humanitarians and their moral stance in war: the underlying values", International Review of the Red Cross, Vol.91, No. 876, 2009.

Watts, Sean. Reciprocity and the Law of War.Harvard International Law Journal, Vol. 50, No. 2, 2009.

Weiss, Martin A., Arab League Boycott of Israel.Congressional Research Service Report for Congress, 19 December 2013 (Found at https://www.fas.org/sgp/crs/ mideast/RL33961.pdf accessed 8 March 2014 at 11.46pm)

Yoo, John, "International Law and the War in Iraq", American Journal of International Law, Vol. 97, 2003.

Charter of the United Nations (1945)

Draft Articles on Responsibility of States for Internationally Wrongful Acts, with commentaries (2001)

Guidelines on the Eligibility of Israeli Entities and Their Activities in the Territories Occupied by Israel Since June 1967 for Grants, Prizes and Financial Instruments Funded by the EU from 2014 Onwards (2013/C 205/05)

International Covenant on Economic, Social, and Cultural Rights (1966)

Rome Statute of the International Criminal Court (1998)

Statute of the International Court of Justice (1946)

Understanding on Rules and Procedures Governing the Settlement of Disputes or Dispute Settlement Understanding (1994)

Application of the Convention on the Prevention and Punishment of the Crime of Genocide, Provisional Measures, Order of 8 April1993, I.C.J. Reports 1993. 
Application of the Convention on the Prevention and Punishment of the Crime of Genocide, Provisional Measures, Order of 13 September 1993, I. C.J. Reports 1993

Arrest Warrant of 11 April 2000 (Democratic Republic of the Congo v. Belgium), Judgment, I.C.J. Reports 2002.

Barcelona Traction, Light and Power Company, Limited, Judgment, I.C.J. Reports 1970.

Gabcikovo-Nagymaros Project (Hungary v. Slovakia), Judgment, 1. C. J. Reports 1997.

Land and Maritime Boundary between Cameroon and Nigeria (Cameroon v. Nigeria: Equatorial Guineu intervening), Judgment, 1. C. J. Reports 2002.

Legal Consequences for States of the Continued Presence of South Africa in Namibia (South West Africa) notwithstanding Security Council Resolution 276 (1970), Advisory Opinion, I.C.J. Reports 1971.

Militarv and Paramilitary Activities in and against Nicaragua (Nicaragua v. United States of America).Merits, Judgment. I.C.J. Reports 1986.

Prosecutor v. Kupreskic, Trial Judgement, at the International Criminal Tribunal for the former Yugoslavia (2000)

Prosecutor v. Tadic, Trial Chamber Decision on the Defence Motion on Jurisdiction, and Appeals Chamber Decision on the Defence Motion for Interlocutory Appeal on Jurisdiction (1995)

Questions relating to the Obligation to Prosecute or Extradite (Belgiumv. Senegal), Judgment, I.C.J. Reports 2012.

R. v Bow Street Stipendiary Magistrate Ex. P. Pinochet Ugarte (No. 3) [2000] 1 A.C. 147

S.S. Lotus (Fr. v. Turk.), 1927 P.C.I.J. (Ser. A) No.10 (Sept. 7)

WTO Dispute Settlement Appellate Body in Case No. WT/DS26/AB/R - WT/ DS48/AB/R, 16 January 1998

WTO Dispute Settlement Body Case No. WT/DS18/R, 12 June 1998

WTO Dispute Settlement Body Case No. WT/DS26/R/USA, 18 August 1997

UN Commission on Human Rights Resolution No. 2001/33

UN General Assembly Resolution No. 1803 (1962)

UN General Assembly Resolution No. 2546 (1969)

UN General Assembly Resolution No. 3171 (1973)

UN General Assembly Resolution No. 3201 (1974)

UN General Assembly Resolution No. 3281 (1974)

UN General Assembly Resolution No. 43/54 (1988)

UN General Assembly Resolution No. A/RES/41/31 (1986)

UN Security Council Resolution No. 418 (1977) 
UN Security Council Resolution No. 665 (1990)

UN Security Council Resolution No. 672 (1990)

UN Security Council Resolution No. 678 (1990)

UN Security Council Resolution No. 687 (1991)

UN Security Council Resolution No. 731 (1992)

UN Security Council Resolution No. 748 (1992)

UN Security Council Resolution No.757 (1992)

UN Security Council Resolution No. 819 (1993)

UN Security Council Resolution No. 827 (1993)

UN Security Council Resolution No. 883 (1993)

UN Security Council Resolution No. 1333 (2000)

UN Security Council Resolution No. 1593 (2005)

UN Security Council Resolution No. 1737 (2006)

UN Security Council Resolution No. 1970 (2011)

ALTSEAN Burma.Ready, Aim, Sanction.Special Report November 2003 (found at http:/ Lwww.altsean.org/Docs/PDF\% 20Format/Special\%20Reports/ Ready\%20Aim\%20Sanction.pdf accessed at 10 March 2014 at 11.51pm)

Australian Government Department of Foreign Affairs and Trade Official Website.Burma Country Brief (found at http://www.dfat.gov.au/geo/ burma/burma_brief.html accessed at 10 March 2014 at 11.53pm)

BBC News. Pinochet Set Free, 2 March 2000 (Found at http://news.bbc.co.uk/1/hi/ uk/663170.stm accessed 8 March 2014, 11.17pm)

ICRC Official Website. Ratification of the Additional Protocols by the United Kingdom of Great Britain and Northern Ireland (found at http:/ / www.icrc.org/ eng/resources/documents/misc/57jp54.htm accessed 6 March 2014, 10.05am)

Official Website of Israel Military Industry (http://imi-israel.com/home/ doc.aspx?mCatID=68506 accessed at 9 March 2014 at 2.40am)

Official Website of Israel Weapon Industry (http://www.israel-weapon.com/ default.asp?catid=\%7BFF7A51A4-4AF9-410D-A2B0-860E9D4F6D2F\%7D accessed at 9 March 2014 at 2.31am)

Official Website of the WTO.Members and Observers (found at http:/ / www.wto.org/ english/thewto_e/whatis_e/tif_e/org6_e.htm accessed 12 March 2014 at $7.16 \mathrm{pm})$

Official Website of the WTO.Principles of the Trading System (found at http:// w w w. wto.org/english/thewto e/whatis e/tif e/ fact2_e.htm\#seeboxaccessed 20 February 2014) 
Resolutions adopted by the GA at its $41^{\text {st }}$ Session (found at http://www.un.org/ depts/dhl/resguide/r41_en.shtml accessed 4 March 2014, at 3.02am)

Security Council Veto List (found at http://www.un.org/depts/dhl/resguide/ scact_veto_en.shtml accessed 4 March 2014 at 3.27am)

The Economist, Sanctions Against Israel: A Campaign That Is Gaining Weight, 8 February 2014 (Found at http:// www.economist.com/news/middle-east-and-africa/ 21595948-israels-politicians-sound-rattled-campaign-isolate-their-country accessed 9 March 2014 at 00.15am)

The Guardian, Ten Days to War, 8 March 2008 (found at http:// www.theguardian.com/world/2008/mar/08/iraq.unitednations accessed 9 March 2014 at 3.16am)

UN Security Council Meeting Record S/PV.2718, 28 October 1986 (found at http:// www.un.org/en/ga/search/view doc.asp?symbol=S/PV.2718, accessed 4 March 2014, 2.51am)

Wall Street Journal.Sanctions Lifted Against Myanmar, 22 April 2013 (found at http:// o n l i n e. w s j. c o m / n e w s / a r t i c l e s/ SB10001424127887323735604578438632149787290 accessed at 11 March 2014 at 00.10am). 